\section{Vegetative Propagation of Five Northern Forest Understory Plant Species from Either Rhizome or Stem Sections}

\author{
Nathalie Nivot \\ Département de phytologie and Département de biologie and Centre d'étude \\ de la forêt, Université Laval, Cité Universitaire, Québec City, Quebec, \\ G1V 0A6, Canada
}

\author{
Alain Olivier \\ Département de phytologie, Université Laval, Cité Universitaire, Québec \\ City, Quebec, GIV 0A6, Canada \\ Line Lapointe ${ }^{1}$ \\ Département de biologie and Centre d'étude de la forêt, Université Laval, \\ Cité Universitaire, Québec City, Quebec, G1V 0A6, Canada \\ Additional index words. Asarum canadense, Caulophyllum thalictroides, Oplopanax horridus, \\ Sanguinaria canadensis, Trillium grandiflorum
}

\begin{abstract}
Five understory plants, Asarum canadense L., Caulophyllum thalictroides (L.) Michx., Sanguinaria canadensis L., Trillium grandiflorum (Michx.) Salisb., of the Northeastern hardwood forests, and Oplopanax horridus (Sm.) Miq., of Western North American temperate forests, are of particular interest for horticultural and natural medicinal products industries. A rapid and efficient propagation method was needed to reproduce these plants vegetatively. To achieve this, the effect of $1000 \mathrm{mg} \cdot \mathrm{L}^{-1}$ (for herbaceous species) or $3000 \mathrm{mg} \cdot \mathrm{L}^{-1}$ (for $O$. horridus) auxin (IBA) and/or cytokinin (kinetin) on the growth of rhizome (for $A$. canadense, $C$. thalictroides, $S$. canadensis, $T$. grandiflorum) or stem sections (for $\boldsymbol{O}$. horridus) was investigated. Nontreated controls were included for each species and an additional control with an intact apical bud was included for $\boldsymbol{A}$. canadense, $S$. canadensis, and $T$. grandiflorum. No vegetative propagation was obtained for $\boldsymbol{T}$. grandiflorum. Survival of $\boldsymbol{O}$. horridus and $\boldsymbol{C}$. thalictroides propagating units was $60 \%$ to $80 \%$ and $90 \%$ to $100 \%$, respectively, and both rooted well even in absence of growth regulators. Asarum canadense produced two times and $S$. canadensis three to four times more roots when treated with the IBA + kinetin or the IBA treatment, respectively, compared with the control rhizome sections without an apical bud. For these two species, the presence of an apical bud enhanced survival and/or shoot emergence and those rhizome sections produced on average more biomass than the other treatments. Our results showed that either rhizome or stem sections can provide an efficient method to propagate $A$. canadense, $C$. thalictroides, $O$. horridus, and $S$. canadensis and thus reduce pressure on wild populations.
\end{abstract}

The market for medicinal plants has been growing steadily with an annual increase of $5 \%$ to $15 \%$ and an estimated value of $\$ 60$ billion U.S. worldwide (Kartal, 2007).

\footnotetext{
Received for publication 22 Feb. 2008. Accepted for publication 14 May 2008.

This work was financially supported by the Conseil des recherches en pêche et en agro-alimentaire du Québec (CORPAQ).

We thank Joanne Turcotte, Annie Goyer, and Isabelle Nadeau for their help in collecting plant material; Marie-Eve Leclerc for help while conducting the experiment; Dr. Jacques-André Rioux and Claude Fortin for advice; Philippe HouleLeroy for assistance during the final harvest; and Andrew P. Coughlan and Julie Bussières for their help improving the manuscript.

${ }^{1}$ To whom reprint requests should be addressed; e-mail Line.Lapointe@bio.ulaval.ca
}

Understory shrubs and herbaceous species with medicinal values have traditionally been harvested from the wild. In addition to collection pressure on understory plants with medicinal properties, demand for indigenous woodland species that have an ornamental value is growing in the North American horticultural market. The lack of information on the most suitable cultivation methods for these ornamental and medicinal species, coupled with the fact that their growth is usually generally discouraged nurseries to grow them commercially.

Collecting plants from the wild reduces the ability of the exploited population to regenerate and also increases variability in the quality of the product. Four herbaceous understory species traditionally harvested from northeast North America, Asarum canslow (Lamoureux and Nantel, 1999), has adense (wild ginger), Caulophyllum thalictroides (blue cohosh), Sanguinaria canadensis (bloodroot), and Trillium grandiflorum (large-flowered trillium), and one woody shrub from northwest North America, Oplopanax horridus (devil's club), were identified as species presenting an economical interest but no commercial method of propagation published to date. The commercial interest for these species, except $T$. grandiflorum, is recent. Although propagation from seeds is an interesting approach because it can lead to the production of many individuals from a single mother plant, its success is limited by the fact that most understory plant species require complex stratification treatments and that the growth of their seedlings is slow (Baskin and Baskin, 1998; Luna, 2001). On the other hand, vegetative propagation could lead to mature individuals after a single year of cultivation.

Several methods for the vegetative propagation of Trillium spp. have been described, all being based on the same principles. Briefly, they consist of reducing or eliminating apical dominance to induce the production of new buds along the rhizome or to stimulate existing dormant buds, both of which result in the formation of small offsets. After the flowering season, the terminal bud can be either girdled or removed and the rhizome replanted. The rhizome can also be cut transversally in two parts, leaving one section with the terminal bud and one without, both sections being replanted. In certain cases, buds along the rhizome are initiated, sprout, and even bloom the next year (Blanchette, 1998; Case and Case, 1997; Edgren, 1993). However, as reported by Case and Case (1997), researchers are still working on efficient propagating techniques that could be applied on a commercial basis for trillium species. The most detailed technique requires the application of a lanolin paste containing cytokinin on the cut surface of the rhizome, then once a callus is formed, a regular application of gibberellin on this callus until it differentiates into a shoot (Edgren, 1993). Such technique can be used by experienced gardeners but is difficult to upscale to commercial production.

The other herbaceous species selected for the present study naturally undergo vegetative propagation by rhizome growth (Lamoureux, 2002; Muir, 1995), whereas lateral branches of $O$. horridus form adventitious roots when in contact with soil (Lantz and Antos, 2002). Rhizome pieces or sections of stems are, therefore, likely to be promising avenues of investigation for the vegetative propagation of these species as recently shown for $S$. canadensis (Onofrietti, 2007). Vegetative propagation from stem tip cuttings has also been described for $O$. horridus (Luna, 2001).

Auxin, more specifically indole-3-butyric acid (IBA), is commonly used by commercial nurseries for induction of adventitious root formation on stem and leaf cuttings (McMahon et al., 2007; Srivastava, 2002), which is a prerequisite for successful propagation. The 
impact of auxin on rhizome sections, however, has not been tested to any great extent so far.

Cytokinins are another class of growth regulators that could be useful by stimulating shoot development of cuttings. A high cytokinin to auxin ratio has been repeatedly shown to promote bud formation and shoot development in plant tissue cultures (Srivastava, 2002). Application of kinetin or benzyladenine, two synthetic cytokinins, to buds induces axillary shoot development by releasing axillary buds from the inhibition caused by apical dominance (Greene and Autio, 1989; Lyons and Hale, 1987). The effect of the application of synthetic cytokinins on underground tissues is less obvious and deserves more studies.

The present study was designed to evaluate the capacity of either rhizome or stem sections from $A$. canadense, $C$. thalictroides, $O$. horridus, $S$. canadensis, and T. grandiflorum to sprout with or without the application of root and/or shoot-inducing growth regulators. The results should help identify the treatments and propagating unit characteristics needed to enhance emergence and subsequent growth from rhizome or stem sections of these five North American understory species during the first year of their establishment.

\section{Materials and Methods}

Manipulation of rhizome and stem sections and treatments applied. From the date of collection or purchase (Table 1), all materials were maintained at $4{ }^{\circ} \mathrm{C}$ under moist conditions until the outset of the experiment in Jan. 2003. This cold storage period was required to break the natural dormancy of the buds because materials were harvested in fall after plants became dormant (Case and Case, 1997; Gracie et al., 2000; Onofrietti, 2007). Rhizome or stem pieces were soaked $(15 \mathrm{~min})$ in a $1.2 \mathrm{~g} \cdot \mathrm{L}^{-1}$ solution of the systemic benzimidazole fungicide $\left(\mathrm{C}_{14} \mathrm{H}_{18} \mathrm{~N}_{4} \mathrm{O}_{3}\right.$; Benlate, DuPont, LA) before cutting them in different sections (Table 1) using surface-sterilized tools. The rhizomes and stems were treated with IBA (SigmaAldrich Canada Ltd., Oakville, Canada), kinetin (6-furfurylaminopurine; SigmaAldrich Canada Ltd.), a mix of both (IBA + kinetin) following the procedure described in Table 1, or left as untreated controls (C). Both IBA and kinetin were first dissolved in a limited volume of ethanol, then the solution was diluted with distilled water to reach final concentrations. A second control called Control $+\mathrm{AB}$ was tested for some of the species (Table 1), in which apical buds (AB) were present to examine the importance of apical dominance on the subsequent development of the plant from rhizome sections and to compare shoot size of already formed buds with shoot size of induced buds.

A second propagation technique, based on the methods described by Edgren (1993), Case and Case (1997), and Blanchette (1998), was tested for T. grandiflorum.
Briefly, whole rhizomes $(\approx 3$ to $4 \mathrm{~cm}$ in length) bearing an apical bud were used. Two incisions $5 \mathrm{~mm}$ in length and $2 \mathrm{~mm}$ deep were made on the top surface of each rhizome to induce the production of offsets. The distal part of the rhizomes (i.e., the oldest part, opposite to the position of the apical bud) was subsequently cut to remove decaying material, and then the cut end of the rhizome was treated with growth regulators as previously described.

Once treated, the stem or rhizome sections were weighed and placed horizontally in 15cm plastic pots containing: 3/1 Plus Planting Mix (Fafard \& Frères ltée, St.-Bonaventure, Canada), vermiculite, and perlite $[3: 1: 1(\mathrm{v} /$ v)]. The pots were transferred to a greenhouse, maintained at $24{ }^{\circ} \mathrm{C}$ day $/ 18{ }^{\circ} \mathrm{C}$ night (16-h photoperiod, natural sunlight supplemented by HPS $400-\mathrm{W}$ lamps), and watered as needed, once every $\approx 2 \mathrm{~d}$. Light in the greenhouse was reduced by the presence of a $50 \%$ shadecloth set up above the supplemental lighting. Mean photosynthetic photon flux density (PPFD) at plant level was 200 $\mu \mathrm{mol} \cdot \mathrm{m}^{-2} \cdot \mathrm{s}^{-1}$. After 3 months of growth, the plants were fertilized twice, at a 2 -week interval, with a $1 \mathrm{~g} \cdot \mathrm{L}^{-1}$ solution of $20 \mathrm{~N}$ 8.8P-16.6K (Plant-Prod-Plus; Plant-Prod Québec, Laval, Canada). Planting occurred from 14 to 18 Jan. 2003 and harvesting time depended on species (Table 1).

Experimental design. The experimental unit comprised a single pot containing a single propagation unit. Each experimental unit was replicated 20 times for each treatment, giving a total of either 80 or 100 (for species with Control $+\mathrm{AB}$ ) plants/species. Because light and temperature were variable across the greenhouse unit, species were put at the most appropriate place based on what is known of their light and heat requirements (Cullina, 2000; Lamoureux, 2002; Small and Catling, 1999) and experimental units were randomized within each species. For example, $A$. canadense and $C$. thalictroides were put in shadier sections of the greenhouse, whereas $O$. horridus was placed in the sunniest area.

Plant measurements. Shoot production was measured at emergence and leaf area was measured either at the outset of leaf senescence or shortly before harvesting if senescence of the aboveground tissues had not occurred during the 4-month growth period. Allometric relations between leaf area, and leaf length and width were established for all herbaceous species using measurements obtained from natural populations (data not shown). These relations were used to estimate leaf area from leaf length and width measured directly on the plant before leaf senescence. The number of roots and buds produced during the 4-month growth period were determined at harvesting. Roots were harvested and divided into new (i.e., paler) and old (i.e., present at the time of planting) roots, dried at $70{ }^{\circ} \mathrm{C}$ for $48 \mathrm{~h}$, and weighed. Visual observations indicated that the old roots did not elongate during the 4month period; their biomass was thus a safe estimate of the initial root biomass at planting. We counted the number of new roots including both new roots that developed on the rhizomes and their lateral roots. Dry biomass values were also obtained for the rhizome or stem sections and for the shoots $\left(70{ }^{\circ} \mathrm{C}\right.$ for $\left.48 \mathrm{~h}\right)$. Rhizome growth was estimated using two methods: the "loss or gain of rhizome biomass" [(dry rhizome biomass $)_{\text {final }}-(\text { dry rhizome biomass })_{\text {initial }}$ ] and the "percentage of rhizome growth" [( $\{\text { dry rhizome biomass }\}_{\text {final }}-\{$ dry rhizome biomass $\left.\left.\}_{\text {initial }}\right) /\{\text { dry rhizome biomass }\}_{\text {initial }}\right]$. The initial dry biomass of the rhizome or stem was calculated using a dry weight/fresh weight ratio that was established using 12 rhizome or stem sections of each species at the outset of the experiment.

Data analysis. The percent emergence was calculated as the number of plants that produced at least one viable shoot out of the 20 plants included in each treatment. The percent survival was measured at harvest as the number of rhizome or stem sections that produced at least one new structure (shoot, root, or bud) during the experimental period. Percent survival and percent emergence were compared between treatments using a $\chi^{2}$ test. Only plants considered to be alive at harvest were used for all other statistical analyses. The impact of the IBA and/or kinetin treatments on the different plant variables (i.e., production of new roots, shoots, and buds and rhizome growth) was investigated using analyses of covariance (ANCOVAs) with initial rhizome biomass (or initial stem biomass in the case of $O$. horridus), shoot biomass (used for one variable in $O$. horridus), and initial root biomass (when present) as covariables. When one of the covariables was significant $(P<0.05)$, results of ANCOVA were presented; otherwise, results of analysis of variance (ANOVA) were presented ( $P$ values) in the different tables. Pearson's correlation tests were run to identify possible relations between the different initial plant variables (i.e., initial root biomass or initial rhizome biomass) and subsequent growth of the propagating units. When strong relations were found for a given species, $t$ tests or ANOVAs were used to more fully characterize those relations. All statistical analyses were performed using Statistix 8.0 for Windows package (Analytical Software, Tallahassee, FL).

\section{Results}

Asarum canadense. After a period of $\approx 6$ weeks in the greenhouse, $61 \%$ of $A$. canadense rhizome sections sprouted (aboveground emergence; data not shown). At harvest, $56 \%$ of the planted rhizomes had developed new roots and shoots, whereas $5 \%$ developed only shoots, $\approx 1 \%$ developed only roots, and 7\% developed only new buds on the rhizome section (data not shown). Survival and all growth variables of $A$. canadense, except the number of new buds, were influenced to some extent by treatments (Table 2). Rhizome sections with apical bud $(\mathrm{C}+\mathrm{AB})$ had the greatest survival rate 


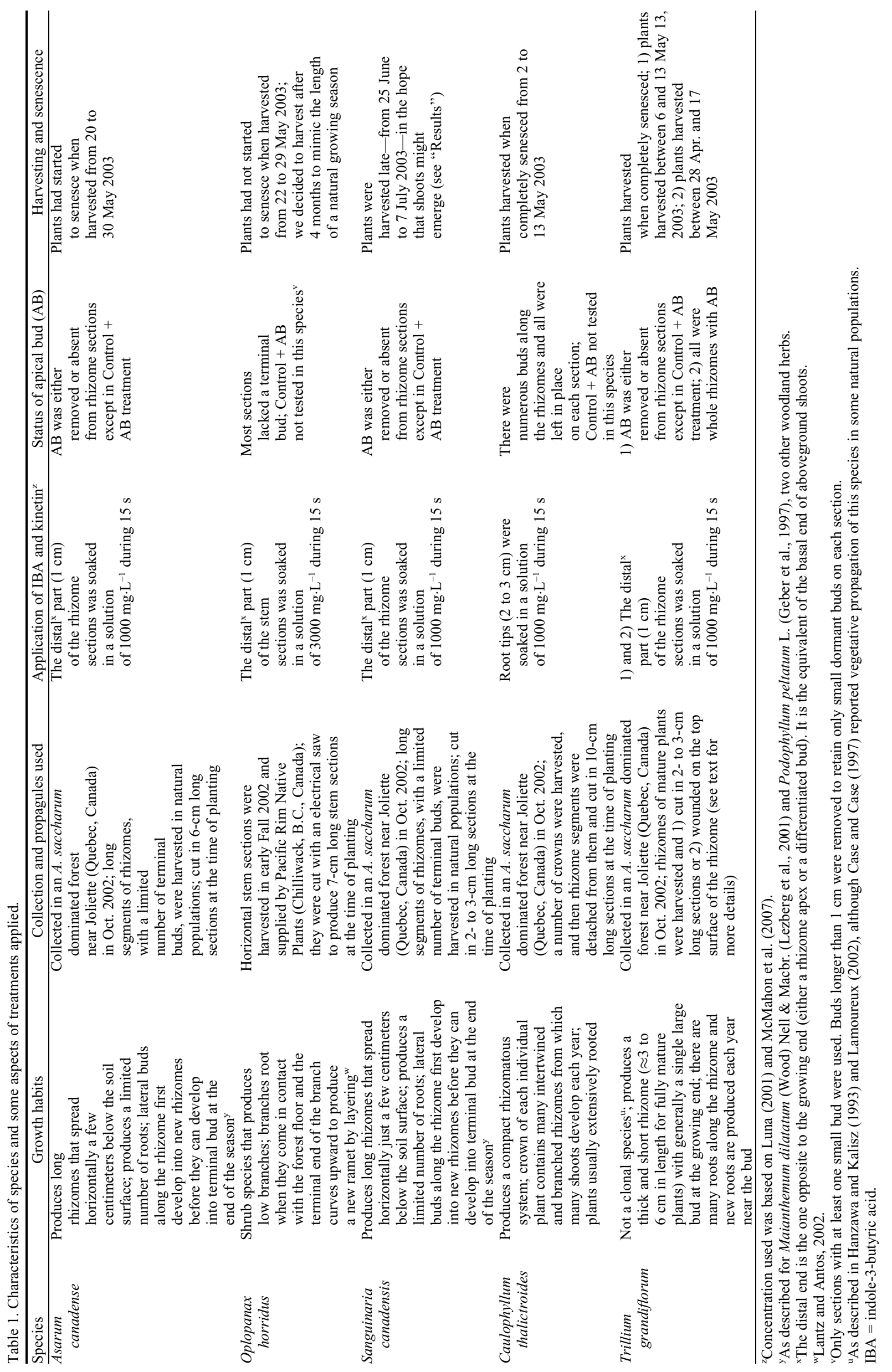


Table 2. Effect of indole-3-butyric acid (IBA), kinetin (Kin), or both (IBA + Kin) as well as the presence of apical bud (Control + AB) on the following variables: survival rate, total leaf area, number of new roots, new root, shoot, and change in rhizome biomass, rhizome growth, and bud number for Asarum canadense rhizome sections ${ }^{\mathrm{z}}$.

\begin{tabular}{|c|c|c|c|c|c|c|c|c|}
\hline & Control & IBA & Kin & $\mathrm{IBA}+\mathrm{Kin}$ & Control $+\mathrm{AB}$ & df error & $F$ & $P$ \\
\hline Survival rate $(\%)$ & 75 & 60 & 65 & 45 & 100 & & & $\mathrm{P}_{\chi 2}: 0.004$ \\
\hline Total leaf area $\left(\mathrm{cm}^{2}\right)^{\mathrm{y}, \mathrm{x}}$ & $24.8 b^{w}$ & $42.2 \mathrm{~b}$ & $32.2 \mathrm{~b}$ & $65.1 \mathrm{a}$ & $69.4 \mathrm{a}$ & 61 & 5.75 & $<0.001$ \\
\hline Number of new roots ${ }^{y}$ & $5.1 \mathrm{c}$ & $8.8 \mathrm{bc}$ & $6.0 \mathrm{c}$ & $11.3 \mathrm{ab}$ & $15.0 \mathrm{a}$ & 63 & 7.44 & $<0.001$ \\
\hline New root dry biomass $(g)^{y}$ & $0.30 \mathrm{c}$ & $0.52 \mathrm{abc}$ & $0.31 \mathrm{bc}$ & $0.65 \mathrm{a}$ & $0.56 \mathrm{ab}$ & 61 & 3.05 & 0.023 \\
\hline Shoot dry biomass $(g)^{y, w}$ & $0.19 \mathrm{c}$ & $0.33 \mathrm{c}$ & $0.27 \mathrm{bc}$ & $0.45 \mathrm{ab}$ & $0.58 \mathrm{a}$ & 61 & 5.62 & $<0.001$ \\
\hline Change in rhizome biomass $(\mathrm{g})^{\mathrm{y}}$ & $-0.03 \mathrm{c}$ & $0.15 \mathrm{bc}$ & $-0.06 \mathrm{c}$ & $0.32 \mathrm{a}$ & $0.23 \mathrm{ab}$ & 62 & 7.34 & $<0.001$ \\
\hline Rhizome growth $(\%)^{\mathrm{y}}$ & $-8.0 \mathrm{c}$ & $28.8 \mathrm{bc}$ & $-12.6 \mathrm{c}$ & $79.6 \mathrm{a}$ & $54.5 \mathrm{ab}$ & 62 & 7.17 & $<0.001$ \\
\hline Number of new buds ${ }^{y}$ & 3.5 & 3.1 & 2.8 & 3.9 & 3.2 & 63 & 0.51 & 0.73 \\
\hline
\end{tabular}

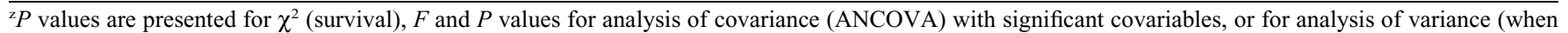
none of the covariables were significant).

'Initial root biomass included as covariable in the ANCOVA.

'Initial rhizome biomass included as covariable in the ANCOVA.

${ }^{w}$ Data within a given row followed by different letters were significantly different.

Table 3. Effect of presence of roots at planting on subsequent growth of rhizome and on production of new roots, shoots, and buds (mean $\pm \mathrm{SE}$ ) and $P$ values for the $t$ tests for Asarum canadense rhizome sections ${ }^{\mathrm{z}}$.

\begin{tabular}{lccr}
\hline & \multicolumn{2}{c}{ State of rhizome sections at planting } \\
\cline { 2 - 4 } & $\begin{array}{c}\text { Absence of roots } \\
(\mathrm{N}=46)\end{array}$ & $\begin{array}{c}\text { Presence of roots } \\
(\mathrm{N}=23)\end{array}$ & $P(t$ test $)$ \\
\hline Number of new roots & $7.9 \pm 1.1$ & $13.1 \pm 1.4$ & 0.005 \\
New root dry biomass $(\mathrm{g})$ & $0.37 \pm 0.05$ & $0.68 \pm 0.08$ & 0.001 \\
Shoot dry biomass $(\mathrm{g})$ & $0.30 \pm 0.04$ & $0.58 \pm 0.08$ & 0.002 \\
Rhizome growth (\%) & $11.6 \pm 9.7$ & $66.7 \pm 13.0$ & 0.001 \\
Number of new buds & $2.6 \pm 0.3$ & $4.5 \pm 0.3$ & $<0.001$ \\
\hline
\end{tabular}

${ }^{\mathrm{x}}$ Data from all treatments are included in these analyses.

Table 4. Effect of indole-3-butyric acid (IBA), kinetin (Kin), or both (IBA + Kin) on survival rate, number of new roots, new root, shoot, and change in stem biomass, stem growth, and bud number for Oplopanax horridus stem sections ${ }^{\mathrm{z}}$.

\begin{tabular}{lccccccc}
\hline & Control & IBA & Kin & IBA + Kin & df error & $F$ & $P$ \\
\hline Survival rate (\%) & 80 & 60 & 80 & 75 & & & $\mathrm{P}_{\chi 2}: 0.43$ \\
Number of new roots & $5.1 \mathrm{~b}^{\mathrm{y}}$ & $5.3 \mathrm{~b}$ & $3.9 \mathrm{~b}$ & $8.7 \mathrm{a}$ & 55 & 5.07 & 0.004 \\
New root dry biomass $(\mathrm{g})^{\mathrm{x}}$ & $2.09 \mathrm{a}$ & $1.50 \mathrm{ab}$ & $0.90 \mathrm{~b}$ & $1.79 \mathrm{a}$ & 54 & 3.71 & 0.017 \\
Shoot dry biomass $(\mathrm{g})^{\mathrm{x}}$ & $4.09 \mathrm{a}$ & $3.73 \mathrm{a}$ & $1.94 \mathrm{~b}$ & $3.38 \mathrm{a}$ & 54 & 4.56 & 0.006 \\
${\text { Change in stem biomass }(\mathrm{g})^{\mathrm{x}}}$ & -1.78 & -1.59 & -1.57 & -0.54 & 54 & 0.43 & 0.73 \\
Stem section growth $(\%)$ & -13.6 & -7.3 & -16.8 & -1.3 & 55 & 2.45 & 0.073 \\
Number of new buds $^{\mathrm{x}}$ & $8.6 \mathrm{a}$ & $7.8 \mathrm{ab}$ & $4.7 \mathrm{~b}$ & $7.5 \mathrm{a}$ & 54 & 3.01 & 0.038 \\
\hline
\end{tabular}

${ }^{\mathrm{z}} P$ values are presented for $\chi^{2}$ (survival), $F$ and $P$ values for analysis of covariance (ANCOVA) with stem biomass as covariable when significant, or for analysis of variance (when stem biomass was not significant as covariable).

${ }^{\mathrm{y}}$ Data within a given row followed by different letters were significantly different.

Initial stem biomass included as covariable in the ANCOVA.

$(100 \%)$. The best growth responses were obtained for rhizome section with apical bud and for those treated with IBA, in particular when combined with kinetin. Control $+\mathrm{AB}$ and $\mathrm{IBA}+$ kinetin produced more than or nearly two times the number of roots, biomass of roots, and shoots and total leaf area compared with the control. Rhizome biomass increased slightly with application of IBA alone but decreased with kinetin application and in absence of growth regulators (Control). The highest increase was observed with IBA + kinetin or in presence of an apical bud (Control $+\mathrm{AB}$ ). Rhizome sections from all groups produced a mean of approximately three new buds.

Further analyses of the data indicated that rhizome sections with roots at the outset of the experiment had better subsequent growth than plants lacking roots at planting (Table 3 ). They produced more shoot and root biomass, more buds, and more rhizome mass than rhizomes devoid of roots at planting. Dry biomass of the new roots was strongly correlated with total leaf area $(r=0.90, P<$ 0.001 ; data not shown).

Oplopanax horridus. Seventy-four percent of $O$. horridus stem sections developed a least one shoot and from those, $86 \%$ rooted as well (data not shown). For most stem sections, sprouting started 2 weeks after the outset of the experiment. The original stem section remained unchanged but new shoots were produced from dormant buds located along this original stem section. At the end of the 4-month experiment, stem sections had developed at least one vertical stem with four to five leaves. Plants treated with the IBA + kinetin produced more roots than the other treatments (Table 4), but because this number was highly variable between plants, root biomass was probably a better estimation of the capacity of these plants to absorb water and nutrients. Kinetin application signifi- cantly reduced root biomass along with shoot biomass. Buds were produced at two locations on the vertical stems: in a crown around the base of the stem and at the point of attachment of each petiole. As a result of the close correlation between the number of buds and the size of the aerial stems, shoot dry biomass was tested as a covariable in the ANCOVA for the number of new buds. When this covariable was included in the statistical model, treatments no longer differed in terms of bud number $(P=0.93$; data not shown). However, when the initial dry biomass of the stem section was included as a covariable, bud production was reduced by kinetin application, most probably through its effect on shoot biomass (Table 4). The initial dry biomass of $O$. horridus stem section positively influenced the dry biomass of new roots and shoots and the production of buds (Table 4; covariable significant). Sprouting capacity was also influenced by the initial biomass of the stem section; stem sections that did not sprout had an initial fresh weight $(\mathrm{FW})$ of $16.7 \pm 2.0 \mathrm{~g}$, whereas those that produced at least one shoot had an initial FW of $26.6 \pm 2.4 \mathrm{~g}$. The initial stem section did not grow, thus explaining the lower final biomass measured for this variable regardless of the treatment.

Sanguinaria canadensis. All S. canadensis rhizome section groups exhibited similar survival rates (95\%; Table 5). However, more shoots emerged from the control group with an apical bud (80\%) than from the others. In contrast to all other species tested, only $10 \%$ of the rhizome sections without an apical bud produced a shoot. Furthermore, many of those that did produce a shoot sustained a Pythium spp.-induced damping off that led to shoot senescence shortly after emergence. This phenomena was also observed in $35 \%$ of the shoots that emerged from the Control $+\mathrm{AB}$ group (all plants with a prematurely senesced shoot were excluded from further analysis). However, rhizomes stayed healthy despite the infection and might sprout again the next year. Of the rhizome sections planted, $85 \%$ produced new roots and $9 \%$ formed only buds along the rhizome section as new structures (data not shown). All rhizome sections that produced new shoot tissue also produced new 
Table 5. Effect of indole-3-butyric acid (IBA), kinetin (Kin), or both (IBA + Kin) as well as the presence of apical bud (Control + AB), on survival and emergence rate, number of new roots, new root, and change in rhizome biomass, rhizome growth, and bud number for Sanguinaria canadensis rhizome sections $\mathrm{z}$.

\begin{tabular}{|c|c|c|c|c|c|c|c|c|}
\hline & Control & IBA & Kin & $\mathrm{IBA}+\mathrm{Kin}$ & Control $+\mathrm{AB}$ & df error & $F$ & $P$ \\
\hline Survival rate $(\%)$ & 100 & 100 & 85 & 100 & 95 & & & $\mathrm{P}_{\chi 2}: 0.08$ \\
\hline Emergence rate $(\%)$ & 15 & 10 & 5 & 10 & 80 & & & $\mathrm{P}_{\chi 2}:<0.001$ \\
\hline Number of new roots ${ }^{y}$ & $3.6 \mathrm{~b}^{\mathrm{x}}$ & $15.8 \mathrm{a}$ & $3.1 \mathrm{~b}$ & $11.5 \mathrm{a}$ & $18.8 \mathrm{a}$ & 79 & 18.05 & $<0.001$ \\
\hline New root dry biomass $(g)^{\mathrm{w}}$ & $0.005 \mathrm{c}$ & $0.010 \mathrm{ab}$ & $0.005 \mathrm{c}$ & $0.006 \mathrm{bc}$ & $0.043 \mathrm{a}$ & 78 & 4.35 & 0.003 \\
\hline \multicolumn{9}{|l|}{ Change in rhizome } \\
\hline biomass $(\mathrm{g})^{\mathrm{w}}$ & $-0.17 \mathrm{~b}$ & $-0.18 \mathrm{~b}$ & $-0.21 \mathrm{~b}$ & $-0.20 \mathrm{~b}$ & $0.65 \mathrm{a}$ & 77 & 5.80 & $<0.001$ \\
\hline Rhizome growth $(\%)^{\mathrm{w}}$ & $-29.2 \mathrm{~b}$ & $-28.0 \mathrm{~b}$ & $-33.6 \mathrm{~b}$ & $-34.9 \mathrm{~b}$ & $165.8 \mathrm{a}$ & 77 & 3.92 & 0.006 \\
\hline Number of new buds ${ }^{v}$ & 1.7 & 1.2 & 1.3 & 1.1 & 2.7 & 52 & 1.91 & 0.12 \\
\hline
\end{tabular}

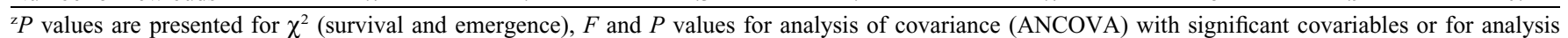
of variance (when none of the covariables were significant).

${ }^{y}$ Statistical analyses were done on $\log \left[\log _{10}(x+1)\right]$ transformed data.

${ }^{x}$ Data within a given row followed by different letters were significantly different.

wStatistical analyses were done on rank-transformed data.

'Initial root and initial rhizome biomass included as covariables in the ANCOVA.

Table 6. Effect of indole-3-butyric acid (IBA), kinetin (Kin), or both (IBA + Kin) on survival rate, total leaf area, number of new roots, new root, shoot, and change in rhizome biomass, rhizome growth, and bud number for Caulophyllum thalictroides rhizome sections ${ }^{\mathrm{z}}$.

\begin{tabular}{lccccccr}
\hline & Control & IBA & Kin & IBA + Kin & df error & $F$ & $P$ \\
\hline Survival rate $(\%)$ & 90 & 100 & 100 & 95 & & & $\mathrm{P}_{\chi 2}: 0.28$ \\
Total leaf area $\left(\mathrm{cm}^{2}\right)$ & 555.9 & 651.9 & 563.0 & 552.9 & 73 & 0.31 & 0.82 \\
Number of new roots & 42.8 & 50.7 & 39.2 & 51.3 & 72 & 0.53 & 0.66 \\
New root dry biomass (g) & 1.02 & 1.13 & 1.14 & 1.05 & 72 & 0.07 & 0.98 \\
Shoot dry biomass (g) & 1.32 & 1.44 & 1.00 & 1.27 & 72 & 1.09 & 0.36 \\
Change in rhizome biomass (g) & -2.04 & -2.14 & -1.96 & -1.86 & 73 & 0.04 & 0.99 \\
Rhizome section growth $(\%))^{\mathrm{y}, \mathrm{x}}$ & -18.0 & -20.6 & -20.8 & -19.9 & 71 & 0.20 & 0.90 \\
Number of new buds & 12.7 & 15.2 & 10.4 & 15.0 & 72 & 1.28 & 0.29 \\
\hline
\end{tabular}

${ }^{\mathrm{z}} P$ values are presented for $\chi^{2}$ (survival), $F$ and $P$ values for analysis of covariance (ANCOVA) with significant covariables or for analysis of variance (when none of the covariables were significant).

${ }^{\mathrm{y}}$ Initial root biomass included as covariable in the ANCOVA.

Initial rhizome biomass included as covariable in the ANCOVA.

Table 7. Effect of indole-3-butyric acid (IBA), kinetin (Kin), or both (IBA + Kin) on survival rate, number of new roots, new root, shoot, and change in rhizome biomass, rhizome growth, and bud number for Trillium grandiflorum rhizome sections with incisions in the top half ${ }^{2}$.

\begin{tabular}{lcccccrr}
\hline & Control & IBA & Kin & IBA + Kin & df error & $F$ & $P$ \\
\hline Survival rate (\%) & 95 & 95 & 100 & 95 & & & $\mathrm{P}_{\chi^{2}}: 0.79$ \\
Number of new roots & 7.1 & 8.0 & 7.1 & 6.3 & 71 & 0.94 & 0.43 \\
New root dry biomass $(\mathrm{g})^{\mathrm{y}, \mathrm{x}}$ & 0.09 & 0.12 & 0.08 & 0.07 & 62 & 0.91 & 0.44 \\
Shoot dry biomass $(\mathrm{g})^{\mathrm{y}, \mathrm{w}}$ & 0.34 & 0.43 & 0.31 & 0.31 & 61 & 1.51 & 0.22 \\
Change in rhizome biomass $(\mathrm{g})^{\mathrm{y}}$ & 0.43 & 0.53 & 0.31 & 0.25 & 62 & 0.29 & 0.83 \\
Rhizome section growth $(\%)^{\mathrm{y}, \mathrm{w}}$ & 31.1 & 35.1 & 25.5 & 22.5 & 61 & 0.04 & 0.99 \\
Number of new buds & 1.00 & 1.06 & 0.95 & 0.95 & & & $\mathrm{P}_{\chi 2}: 0.80$ \\
\hline
\end{tabular}

${ }^{z} P$ values are presented for $\chi^{2}$ (survival and bud number), $F$ and $P$ values for analysis of covariance (ANCOVA) with significant covariables or for analysis of variance (when none of the covariables were significant).

${ }^{\mathrm{y}}$ Initial root biomass included as covariable in the ANCOVA.

${ }^{\mathrm{x}}$ Statistical analyses were done on rank-transformed data.

winitial rhizome biomass included as covariable in the ANCOVA.

roots. Rhizomes with an apical bud and those treated with IBA produced the highest root biomass, whereas the number of new roots was at least three times higher for IBA, IBA + kinetin, and Control $+\mathrm{AB}$ than for kinetin alone or the control (Table 5). Because of the low percent emergence, evaluating the effect of IBA and kinetin on shoot biomass was impossible. Rhizome sections with an apical bud increased their total rhizome mass by $166 \%$, whereas all other groups exhibited a mean decrease of $31 \%$. The number of new buds produced was 1.5 on average, independently of the treatment (Table 5), but almost half of the rhizome sections treated with IBA failed to produce any buds (data not shown). Furthermore, the number of buds produced was influenced by the initial rhizome and root mass because the inclusion of these covariables in the statistical model failed to reveal differences between treatments $(P=0.12)$. Rhizomes sections with an apical bud had more roots at planting than the other treatment groups $(P<0.001$; data not shown $)$.

Caulophyllum thalictroides. Ninety-six percent of the $C$. thalictroides rhizome sections produced new structures and $81 \%$ sprouted (data not shown). All rhizome sections that sprouted developed new roots, only $9 \%$ of rhizome sections rooted without producing shoots, and $6 \%$ only formed new buds on the rhizome sections (data not shown). Most of the shoots emerged 1 week after planting. Neither sprouting nor other mea- sured variables responded to the treatments (Table 6). At the end of the experiment, the rhizomes had lost an average of $2 \mathrm{~g}$ or $20 \%$ of their initial biomass and produced an average of 46 new roots (for a dry biomass of $1 \mathrm{~g}$ ), two new stems (with a total leaf area of $582 \mathrm{~cm}^{2}$ ), and 13 new buds/rhizome.

The initial biomass of roots at planting was correlated $(P<0.001$, data not shown $)$ with new root dry biomass production $(r=$ $0.52)$, shoot dry biomass $(r=0.79)$, and total leaf area $(r=0.68)$. Initial rhizome section biomass was negatively correlated with the percent increase in rhizome biomass $(r=$ $-0.43, P<0.001$ ). Furthermore, bigger rhizomes produced smaller shoot biomass $(r=$ $-0.60, P<0.001)$ and total leaf area $(r=-0.64$, $P<0.001)$ when both were expressed on a per gram of initial rhizome section biomass.

Trillium grandiflorum. Only $21 \%$ of the $T$. grandiflorum rhizome sections without an apical bud produced new roots or buds on the rhizome section, and none sprouted (data not shown). Although only $3 \%$ of the rhizome sections rotted, the rhizome sections that did not produce any new structures $(79 \%)$ were considered dead. On the other hand, all rhizome sections with an apical bud produced a shoot and some new roots except for one rhizome section that rotted. The limited data for rhizome sections with new structures thus prevented comparisons between treatments. Cutting rhizome sections of $T$. grandiflorum into two pieces failed as a propagation method, even when combined with IBA, kinetin, or both treatments, because in most cases, only the section with the apical bud survived.

Of those $T$. grandiflorum rhizomes that had incisions in the top half (wounded), 96\% produced at least one new structure and $91 \%$ sprouted (Table 7). Neither emergence nor growth variables responded to treatments. On average, rhizomes produced seven new roots for a mean dry biomass of $0.09 \mathrm{~g}$, developed $0.35 \mathrm{~g}$ of new shoot tissue, and their rhizome biomass increased by $0.38 \mathrm{~g}$ or $25 \%$. Only two rhizome sections (one control and one IBA-treated) produced new buds at the site of the incisions. For all the other rhizomes, the wounded areas had healed over and the only bud that develops on these rhizomes was in the apical position. Overall, a high initial 
rhizome biomass, coupled with a high root biomass at planting, enhanced subsequent shoot production (data not shown).

\section{Discussion}

Percent survival of rhizome and stem sections. The use of rhizome or stem sections seems to be a satisfactory technique for the propagation of $O$. horridus, $S$. canadensis, and $C$. thalictroides. Shoot emergence of $O$. horridus was $74 \%$ and that of $C$. thalictroides was $81 \%$. New roots were produced on $64 \%$ of $O$. horridus shoot sections and on $85 \%$ of $S$. canadensis and $90 \%$ of $C$. thalictroides rhizome sections. By contrast, only $61 \%$ of A. canadense rhizome sections produced a shoot and $57 \%$ produced new roots. Survival was not linked to initial rhizome biomass in this species (data not shown). However, the presence of roots at planting was positively correlated with new root biomass, shoot biomass, and percent rhizome growth. The initial presence of roots may have influenced rhizome section survival. Unfortunately, verifying this point was impossible because dead rhizomes decomposed before the end of the experiment. The irrigation regime may also have applied too much water for this species, which caused rotting of the rhizomes before sprouting, as noticed by G. Dostie (U. Sherbrooke, personal communication). Asarum canadense rhizome is apparently prone to rotting when poorly rooted.

The high survival rates obtained for stem sections of $O$. horridus were probably the result of the natural ability of this species to propagate by layering and by sprouting from basal stems (Lantz and Antos, 2002). We found that stem sections that weighed more than $16.7 \mathrm{~g} \mathrm{FW}$ were more likely to survive than smaller ones, supporting results obtained from previous studies on woody and semiwoody species (Chalapathi et al., 2001; Palanisamy and Kumar, 1997). Total nonstructural carbohydrates have been shown to influence rooting by providing energy reserves and a carbon skeleton to support root initiation and subsequent growth (Haissig, 1986; Veierskov, 1988).

In the present study, all attempts to propagate $T$. grandiflorum failed. $T$. grandiflorum rhizome sections, without the application of growth regulators, remain the traditional propagation methods for this species (Case and Case, 1997), but the percentage of success using this technique is low. In contrast to the results obtained by Edgren (1993) and Blanchette (1998), superficial wounding applied on whole rhizomes, whether disbudded or not, failed to induce bud formation in the present study. The incisions may have been too shallow [Blanchette (1998) used 3- to 5-mm deep incisions] and perhaps healed over before inducing bud formation. Another possible reason underlying the poor results with this species may be related to intraspecific genetic variations within colonies or populations, which could result in a lower capacity of certain individuals to regenerate vegeta- tively. This possibility was advanced by Case and Case (1997), who observed high vegetative reproduction rates for certain of their own T. grandiflorum clones, whereas the cloning ability of this species was considered by some authors to be nonexistent (Hanzawa and Kalisz, 1993) or rare (Lamoureux, 2002). Therefore, studying the intraspecific genetic variation of $T$. grandiflorum with regard to cloning ability could be of considerable practical value for future commercial propagation of this species.

Treatment effects. For $A$. canadense and $S$. canadensis, treating rhizome sections with IBA or IBA + kinetin enhanced root production. The general effect of auxin on adventitious root production is well known (Loach, 1988; McMahon et al., 2007; Srivastava, 2002). For A. canadense rhizome sections, root biomass appears to influence both rhizome growth and shoot production. This indicates that better-rooted rhizome sections were able to take advantage of an increase in shoot biomass and leaf area, which likely increased the amount of carbon fixed and resulted in larger resources for rhizome growth compared with lightly rooted rhizome sections. Therefore, providing favorable conditions to promote good rooting appears important for the production of healthy $A$. canadense plants from rhizome sections, which in turn should enhance survival of these plants over time and may be of particular importance for species that are normally characterized by a limited number of superficial roots such as $A$. canadense and $S$. canadensis.

For $O$. horridus, IBA failed to affect root production on stem sections. This species undergoes natural layering (Lantz and Antos, 2002) and thus has a good inherent rooting capacity. In the present study, stem sections produced a large root biomass irrespective of treatment. Auxin (IBA) application also failed to improve the rooting capacity of $C$. thalictroides. The application of IBA to the apical end of roots in this species, contrary to an application to the distal part of the rhizome, may have impeded the expected rootpromoting effect of the IBA treatment. By contrast, the initial biomass of roots on rhizome sections at planting was important and positively influenced both production of new roots and shoots. Although the present study was unable to show a positive effect of auxin on root formation, the effect of IBA on poorly rooted stem sections of C. thalictroides should be tested.

Interestingly, the species that produced the fewest roots (e.g., A. canadense and $S$. canadensis) were also those that were the most sensitive to IBA application. This situation is frequently observed and could be explained by the fact that the ability of a given species or cultivar to root seems to be related to its endogenous indole acetic acid (IAA) content (Srivastava, 2002). An exogenous auxin application would consequently correct for the lack of IAA in A. canadense and $S$. canadensis, but would have little effect on species such as $O$. horridus, which might already have a high level of endogenous IAA.
Kinetin had a negative effect on root, shoot, and bud production of $O$. horridus. Cytokinins, when in too high a concentration, are known to have an adverse effect on root formation (Srivastava, 2002), which may explain why fewer roots formed on kinetintreated stem sections than on stem sections receiving the other treatments. This result in turn probably explains why kinetin-treated stem sections produced less shoot biomass than stem sections receiving the other treatments.

Kinetin treatment failed to stimulate formation of adventitious buds (reviewed by Cline, 1991) in all five species. In the case of A. canadense, each Control $+\mathrm{AB}$ rhizome section produced, on average, 3.2 new lateral buds, indicating that apical dominance is weak in this species and unlikely to influence its vegetative propagation. Similarly, Control + AB rhizome sections of $S$. canadensis produced 2.7 buds on average, indicating that at least two shoots per plant would sprout the next year. There are conflicting results in the literature about the effect of cytokinin on lateral bud development. The cytokinin benzyl adenine, when applied basally, favored lateral bud development in Arabidopsis cuttings, but when applied apically, they remained dormant (Chatfield et al., 2000). Srivastava (2002) also reported that the application of cytokinins, alone or with auxin, to the apical end of a decapitated stem fails to release lateral buds from inhibition and may even reinforce inhibition. Application of benzylaminopurine, a synthetic cytokinin, to the basal part of rootless shoot cuttings of Solanum tuberosum spp. andigena Hawkes induced lateral shoot development (Woolley and Wareing, 1972). On the other hand, cytokinins stimulated bud development when applied to the lateral buds of plants with an intact apex (Srivastava, 2002) or to decapitated plants to which inhibitory concentrations of apical auxin were applied (Mok, 1994). Thus, application of exogenous cytokinins to either lateral buds directly or to the basal part of the stem like in the present study has been shown to release lateral buds from inhibition, but timing of application or concentrations might explain the lack of effect on the species under study.

Rhizome growth. In the present study, experiments were stopped after 4 months and measurements were taken at shoot senescence for each species except $O$. horridus, which was harvested before senescence. Nevertheless, rhizome biomass decreased for three of the species. Such a loss was anticipated for rhizome sections of $S$. canadensis, which used existing reserves to produce new buds and roots without producing shoots. This result was supported by the fact that control plants of $S$. canadensis possessing an intact apical bud (Control $+\mathrm{AB})$, of which nearly all sprouted, exhibited a significant increase in rhizome biomass during the growth season. With regard to O. horridus, examination of the stem sections revealed an old dehydrated stem section, suggesting that the new shoots became partially or totally 
independent of the initial horizontal stem section. In the case of $C$. thalictroides, a reduction in rhizome biomass was also observed irrespective of treatment. The reason behind this reduction is unclear. The rhizomes were alive and lacked decay, and the shoots, which had undergone a 4-month growth period, had all senesced naturally. Carbon reserves should have been translocated to the rhizome before harvesting. The fact that bigger rhizomes produced proportionally less shoot biomass and leaf area than smaller rhizomes might explain the negative correlation between rhizome size and growth observed for this species. Larger rhizomes would produce insufficient leaf area to allow rhizome growth either through production of new tissues or accumulation or reserves. However, the factor that limits shoot production by larger rhizomes must still be explained.

In conclusion, the present study has shown that untreated rhizome sections of $C$. thalictroides and stem sections of $O$. horri$d u s$, and IBA-treated rhizome sections of $S$. canadensis and $A$. canadense, are efficient methods for vegetative propagation of these species. Rhizomes of $C$. thalictroides responded well to cutting provided that the rhizome sections weighed less than $20 \mathrm{~g} \mathrm{FW}$ and were well furnished with roots at the time of planting. Stem sections of $O$. horridus (initial fresh weight greater than $16.7 \mathrm{~g}$ ) rapidly established new roots and shoots. Rhizome sections of $S$. canadensis survived at high rate and IBA enhanced formation of new roots. The new buds produced during the first growing season would be expected to emerge the next year (Onofrietti, 2007). However, Pythium can attack S. canadensis shoots if the substrate is too moist (Greenfield et al., 2006). Rhizome sections of $A$. canadense generally responded well when used as propagating units but are susceptible to rotting when poorly rooted. Auxin application is recommended for vegetative propagation by rhizome sections for this species. The cytokinin kinetin was ineffective in stimulating either adventitious or axillary buds in any of the five species in contradiction to its effectiveness for this purpose in tissue culture propagation systems. None of the vegetative propagation treatments resulted in established plants of $T$. grandiflorum. Deeper incision of the rhizome, clonal differences in their ability to propagate vegetatively (Case and Case, 1997), in vitro propagation techniques (Pence and Soukup, 1993), and production from seeds (Solt, 2002) are among possible avenues of research for this species. The techniques used in the present study can be easily used in commercial nurseries as well as to set up plantations in the understory of hardwood forests. Other plant growth regulators and/or concentrations need to be tested in the future to further improve rooting and bud production. Harvesting mother plant material at other times during the year could also influence survival and sprouting in some of these species.

\section{Literature Cited}

Baskin, C.C. and J.M. Baskin. 1998. Seeds: Ecology, biogeography, and evolution of dormancy and germination. Academic Press, San Diego, CA.

Blanchette, L. 1998. Asexual propagation of Anemonella, Dodecatheon, and Trillium. Combined Proc. Intl. Plant Propagators Soc. 48:327-328

Case, F.W., Jr. and R.B. Case. 1997. Trilliums. Timber Press, Portland, OR.

Chalapathi, M.V., S. Thimmegowda, N.D. Kumar, G.G.E. Rao, and K. Mallikarjuna. 2001. Influence of length of cutting and growth regulators on vegetative propagation of Stevia (Stevia rebaudiana Bert.). Crop. Res. 21:53-56.

Chatfield, S.P., P. Stirnberg, B.G. Forde, and O. Leyser. 2000. The hormonal regulation of auxiliary bud growth in Arabidopsis. Plant J. 24:159-169.

Cline, M.G. 1991. Apical dominance. Bot. Rev. $57: 319-358$

Cullina, W. 2000. The New England Wildflower Society's guide to growing and propagating wildflowers. Houghton Mifflin, Boston, MA.

Edgren, M. 1993. Vegetative propagation of Trillium chloropetalum. Bull. Amer. Rock Garden Soc. 51:169-172.

Geber, M.A., H. de Kroon, and M.A. Watson. 1997. Organ preformation in mayapple as a mechanism for historical effects on demography. J. Ecol. 85:211-223.

Gracie, A.J., P.H. Brown, S.W. Burgess, and R.J. Clark. 2000. Rhizome dormancy and shoot growth in myoga (Zingiber mioga Roscoe). Sci. Hort. 84:27-36.

Greene, D.W. and W.R. Autio. 1989. Evaluation of benzyladenine as chemical thinner on 'McIntosh' apples. J. Amer. Soc. Hort. Sci. 114:6873.

Greenfield, J., J.M. Davis, and K. Brayman. 2006. Bloodroot (Sanguinaria canadensis L.). NC State Univ. Hort. Info. Lflt. 134.

Haissig, B.E. 1986. Metabolic processes in adventitious rooting of cuttings, p. 141-190. In: Jackson, M.B. (ed.). New root formation in plants and cuttings. Martinus Nijhoff Publishers, Dordrecht, The Netherlands.

Hanzawa, F.M. and S. Kalisz. 1993. The relationship between age, size, and reproduction in Trillium grandiflorum (Liliaceae). Amer. J. Bot. 80:405-410.

Kartal, M. 2007. Intellectual property protection in the natural product drug discovery, traditional herbal medicine and herbal medicinal products. Phytotherapy Res. 21:113-119.
Lamoureux, G. 2002. Flore printanière. Fleurbec. Saint-Henri-de-Lévis, Quebec, Canada.

Lamoureux, G. and P. Nantel. 1999. Cultiver les plantes sauvages ... sans leur nuire. Fleurbec. Saint-Henri-de-Lévis, Quebec, Canada.

Lantz, T.C. and J.A. Antos. 2002. Clonal expansion in the deciduous understory shrub, devil's club (Oplopanax horridus; Araliaceae). Can. J. Bot. 80:1052-1062.

Lezberg, A.L., C.B. Halpern, and J.A. Antos. 2001. Clonal development of Maianthemum dilatatum in forests of differing age and structure. Can. J. Bot. 79:1028-1038.

Loach, K. 1988. Hormone applications and adventitious root formation in cuttings: A critical review. Acta Hort. 227:126-133.

Luna, T. 2001. Propagation protocol for Devil's club (Oplopanax horridus). Native Plants J. 2:106-108.

Lyons, R.E. and C.L. Hale. 1987. Comparison of pinching methods on selected species of $\mathrm{Col}$ umnea, Kalanchoe, and Crassula. HortScience 22:72-74.

McMahon, M.J., A.M. Kofranek, and V.E. Rubatzky. 2007. Hartmann's plant science: Growth, development and utilization of cultivated plants. 4th Ed. Pearson Prentice Hall, Upper Saddle River, NJ.

Mok, M.C. 1994. Cytokinins and plant development: An overview, p. 155-156. In: Mok, D.W.S. and M.C. Mok (eds.). Cytokinins, chemistry, activity and function. CRC Press, Boca Raton, FL.

Muir, A.M. 1995. The cost of reproduction to the clonal herb Asarum canadense (wild ginger). Can. J. Bot. 73:1683-1686.

Onofrietti, M. 2007. Propagation and cultivation of Bloodroot (Sanguinaria canadensis). North Carolina State Univ., Raleigh, NC. MS Thesis.

Palanisamy, K. and P. Kumar. 1997. Effect of position, size of cuttings and environmental factors on adventitious rooting in neem ( $\mathrm{Aza}$ dirachta indica A. Juss). For. Ecol. Manage. 98:277-280.

Pence, V.C. and V.G. Soukup. 1993. Factors affecting the initiation of mini-rhizomes from Trillium erectum and T. grandiflorum tissues in vitro. Plant Cell Tissue Organ Cult. 35:229235 .

Small, E. and P.M. Catling. 1999. Canadian medicinal crops. National Research Council of Canada, Ottawa, Ontario, Canada.

Solt, S. 2002. Propagation protocol for Trillium L. (Liliaceae). Native Plants J. 3:18-20.

Srivastava, L.M. 2002. Plant growth and development: Hormones and environment. Academic Press, San Diego, CA.

Veierskov, B. 1988. Relations between carbohydrates and adventitious root formation, p. 70 78. In: Davis, T.D., B.E. Haissig, and N. Sanhla (eds.). Adventitious root formation in cuttings. Dioscorides Press, Portland, OR.

Woolley, D.J. and P.F. Wareing. 1972. The interaction between growth promoters in apical dominance. I. Hormonal interaction, movement and metabolism of a cytokinin in rootless cuttings. New Phytol. 71:781-793. 